\title{
Developing Students Work Readiness Model on Accounting Program of Vocational High School (VHS) Base on I-E-0 Astin Model
}

\section{Muhammad Feriady and Heri Yanto}

Lecturer of Economic Education Department, Faculty of Economic, UNNES

\section{Abstract}

The purposes of this research is to developing Vocational High School (VHS) student work readiness model base on I-E-O Astin's theory. Locus of control, academic achievement and family support are educational input. Student Engagement on internship program is a proxy for Environment and Outcome respectively. This research uses path analysis to analyze the relationship among variables. In addition, qualitative analysis is also used to explain about student involvement in internship. The number

Corresponding Author: Muhammad Feriady mferiady@mail.unnes.ac.id

Received: 7 August 2018 Accepted: 15 September 2018 Published: 22 October 2018

Publishing services provided by Knowledge E

(c) Muhammad Feriady and Heri Yanto. This article is distributed under the terms of the Commons Attribution License, which permits unrestricted use and redistribution provided that the original author and source are credited.

Selection and Peer-review under the responsibility of the ICE-BEES 2018 Conference Committee. of population in this research is 686 respondent of Accounting Program VHS Student in Purbalingga Regency with 247 respondent as sample. The Study found that there is influence between locus of control and family support to Student engagement and work readiness. Student engagement have significant influence to work readiness. Academic achievement influence un-significant to student engagement but have significant influence to work readiness. Student Engagement in internship program effectively mediates the influence of locus of control and family support on student work readiness. Suggestion from this research is educational institute must maximize the Student Engagement in internship program to maximize student work readiness. The industries should extend more chance to student explored the task on internship program.

Keywords: Student Engagement, I-E-O Models, Work Readiness, Internship Program, Vocational High School

\section{Introduction}

One of the Standard in Education Graduates of Vocational High School is having a work readiness in accordance with expertise. It was explained in "Pasal 15 UU 20 Tahun 2003 tentang Sistem Pendidikan Nasional", stated that "Vocational education is high education that used to preparation for students to work in a particular field". Therefore, the 
implementation of vocational high schools can produce graduates (output) that ready to work and have competencies that needed in the business world. Work readiness becomes an important factor for graduates of Vocational High School as a provision to enter in the workforce.

Work readiness is influenced by the processes of education and student input. Astin in Yanto (2011:4) describes about the process of education approach, educational institutions process input in the form of the background of the students, and it is processed in the environment to obtain the outcomes (results achieved). Hereafter, the theory of the Astin is model of I-E-O Astin's Approach (Input-Environment/process-outcomes). The application of this model has been made in investigations of the influence of the educational process as a variable that connects the input with the output.

The development model of Astin emphasized the activity of the students engagement as input in an educational environment. I-E-O model is adapted to explain for the relationship between environmental education and student input [13]. Norwani said that the use of I-E-O model from Astin can be known the influence of institutions on the development of students. It means that the work readiness as the purpose of Vocational High School is influenced by the students engagement in the learning environment.

The use of I-E-O Model in some of the research is used to reveal the influence of environmental education in the changing educational inputs into outcomes. Watson in Norwani (2003:11) explains that there is little influence between the background of the students towards academic achievement when compared with environmental factors of education. It is due to the convenience of the relationship between teachers with students, it can increase student engagement in learning. Terenzini, Cabrera and Colbeck (1999:8) explained that environmental factors are very important in influencing to solve some problems and ability of members in an organization.

As for the definition of the Input is an inherent condition that attached to the students including demographic backgrounds, interests and talents, physical conditions, and environment ([8]:5). Environment is defined as everything that created as a learning environment in schools when students can be learning experiences, while outcomes are the results which include knowledge, values, attitudes, beliefs, etc. ([8]:5).

Looking at internship Program as the environment for student's learning, then based on the theory of Astin about the student engagement in internship program is one of the factors that determine the work readiness. Internship is also related to the granting of work experience that it makes the students acquainted with the world of work. It is stated by Gohringer (2002:4), the educational program in Germany combines between 
theory and practice where students are considered in need of the program's trainees before plunging into the world of work, so that someone who internships provide different skills and knowledge, so that it is able to produce a work ethic that is widely accepted by Government, industry and social partners.

Work readiness according to ACT (2013:7) is a basic skills that should be had to be minimally qualified for a particular job. The student's work readiness skills of Accounting Program in VHS at Purbalingga Regency still looks low. The low of work readiness can be seen from many students who have not knowledge about working in industry or companies. In addition, through the preliminary observation was still found the number of students who have not a work plan.

Work readiness as outcomes of vocational education influenced by inputs and environment students factor. In this study, researchers proposed student input factors of students' academic achievement, Locus of Control, and also the support of parents. In addition to the input factor, the factor of environment has also affected with work readiness. While the environmental factors in this study will be measured by using student engagement in OJT. Similarly, Yanto (2011) stated that input factors such as student motivation, the academic experience of students, demographic conditions, and facilities for student learning as educational inputs. Other researchers, Ani (2013) proposes that the conditions of family and student communities as an input factors of the students with outcomes of interest in entrepreneurship. Both of these researchers use student engagement as mediators from the input towards outcomes.

Based on preliminary study, the factors were affecting the work readiness of the VHS student at Purbalingga regency, and it had good symptoms. It can be seen from the high academic achievement of students as measured by the value of the productive subjects. In addition to academic achievement, the locus of control of students also had good symptoms. It can be seen from the enthusiasm of the students when they were involving in Internship Program. In addition, a good preparation from the students showed that students were very ready to succeed the internship program. Locus of Control according to the Rooter in Daum and Glendon (2003:31) is a situation where we believe or are not able to determine what happens to us.

Preliminary observation conducted by researchers also found that the support of parents had good symptoms. According to the data of interviews about the support of parents to students like helping to find a boarding place for students who got a far place for internship program. Other things that parents also provide an additional allowance, pick up from internship place, supervise for assignment that students are carried out. Based on the data of the interview also found that the parents helped their son to 
create a good relation with their internship place, so the students will feel comfortable at work. Parents support according to Curtona in Rissa (2013:7) consist of instrumental support, i.e. direct support in the form of granting facilities and assistance.

Based on the background of discussion can be established the problem in this research. The research problem in this paper described that work readiness of VHS student in accounting program is still low, While the factors that influence, it shows good and high symptoms. this is contrary to the theory of astin that explains that the output of the educational process is influenced by internal factors of students. furthermore, we need to analyze deeper about the application of Astin's theory in the Vocational Education areas.

This research focus to use Astin's Model to explain phenomena about Vocational High School (VHS) student work readiness factor. Base on the research problem we can conclude the hypothesis in this research is:

H1: VHS student work readiness is affected by student academic achievement

H2: VHS student work readiness is affected by student locus of control

H3: VHS student work readiness is affected by family support

H4: VHS student work readiness is affected by Student engagement on internship program

H5: student engagement on internship program is affected by Academic achievement

H6: student engagement on internship program is affected by student locus of control

H7: Student Engagement on Internship Program is affected by family support

H8: student engagement on internship program is a mediator to increasing affection of locus of control to student work readiness

H9: student engagement on internship program is a mediator to increasing affection of family support to student work readiness

\section{Literature Review}

\subsection{I-E-O Astin's model}

Input-Environmental-Outcomes model is a model that developed by Astin (1986) based on research in higher education. The basic concept of the I-E-O model is how 
in the learning result in an education determined by three factors, namely the Input, Environment, and outcomes. This model was originally devolved by Astin from some research conducted in College ([8]:8).

But according to Astin in Dixon (2012:8) describes that the inputs, Outcomes, and Environmental consists of: Input is input in the process of education that is owned by the student before entering into the educational environment, consists of: previous experience, demographic and background (psychological) of students. Environmental is a learning environment where students gain experiences to learn and perform interaction, including other various experiences during the study period. Outcomes is the output (result) of the educational process which has done in the environmental interactions of students in education, consists of: the characteristics, attitudes, knowledges, values obtained during the study period.

\subsection{Student engagement}

Student engagement is defined as the quality of students independence in devoting attention to the learning activities in order to achieve the desired results (Hu and Kuh: 2002, Zhou 2010:7). According to Chapman, 2003 (in Zhou 2010:7), student engagement is the willingness of students to participate in activities such as attending classes, sending the work required, and getting assignments. Besides William in Mizikazi (2006:13) stated that the student engagement is how students plunged into schools and unengagement of students refers to how students withdrew from school directly. From some explanation, it can be inferred that the student engagement is the way how the students plunged in various activities to achieve the purpose of learning.

\subsection{Work readiness}

According to ACT (2013:7) stressed that the work readiness on the aspect of a skill is, "A Definition of Work Readiness "work ready" individual possesses the foundational skills needed to be minimally qualified for a specific occupation the US determined through a job analysis or occupational profile ". It means that the definition of work readiness refers to the basic skills that should be owned to be minimally qualified for a particular job profile. It can be concluded that the work readiness is an initial condition that must be owned by someone to do a job to produce goods or services. 


\subsection{Locus of control}

According to Robbins (2007:139), Locus of Control is the level which individuals are convinced that they are deciding their own fate. Likewise, the locus of control in students deemed to affect the amount of the ability to transfer their new skills. Rotter (in Suwarsi \& Budianti, 2009:8) explains that the Locus of control is certainly a thing that contributes to the quality of performance at someone, that is the initial response as the basis of the response will do next. It means that the locus of control has a role in improving the performance of someone from either internal or external.

\subsection{Support parents}

Social support given by parents is important with student' career progress including work readiness. Weiss and Curtona in Rissa (2013:7) describes that the support of parents can be done in some form as follows: 1) emotional support, 2) awards support, 3) instrumental support, 4) information support, and 5) social network support.

\section{Research Methods}

This study used mix research (mix method) approach with a strategy developed strategy refers to the congruent insertion (embedded congruent). This approach combines quantitative with qualitative analysis where qualitative data is used to be complementary of data in quantitative analysis that done ([6]:273).

In the mixed research, the research data consists of quantitative and qualitative data. Quantitative data can be either primary or secondary data in the form of numbers. The characteristic of quantitative data is able to be processed or analyzed by using statistical or mathematics calculations. The quantitative data in this study sourced from a questionnaire that distributed to 247 samples of respondents from 686 students population of accounting programs in VHS at Purbalingga in 2016.

The form of qualitative data is a primary or secondary data. According to Lofeland in Moleong (2013:157), the main sources of data in qualitative research were the words and actions, documents, and others. The characteristic of qualitative data is deep and comprehensive. The data will be obtained in depth using structured interview. As for the informant interviews comprised of representatives of students, representatives of the industry and the representative of the committee of internship program. 
Analysis in this study used quantitative and qualitative analysis. In the quantitative analysis used path analysis by first testing the conformance model. Program AMOS Version 22 is used to quantitative analysis. The qualitative analysis in this study is using the Miles and Hubermen model analysis.

Variables in quantitative analysis are developed in this study consisted of endogenous and exogenous variable. Endogenous variable or variable that influenced in this study consists of a work readiness and student engagement in internship program. Exogenous variables in this study consists of the student's academic achievement, Locus of Control and support of parents. The operational definition of each variable is as follows:

Based on the operational definition of the variables, we can describe the structural model diagram as follows:

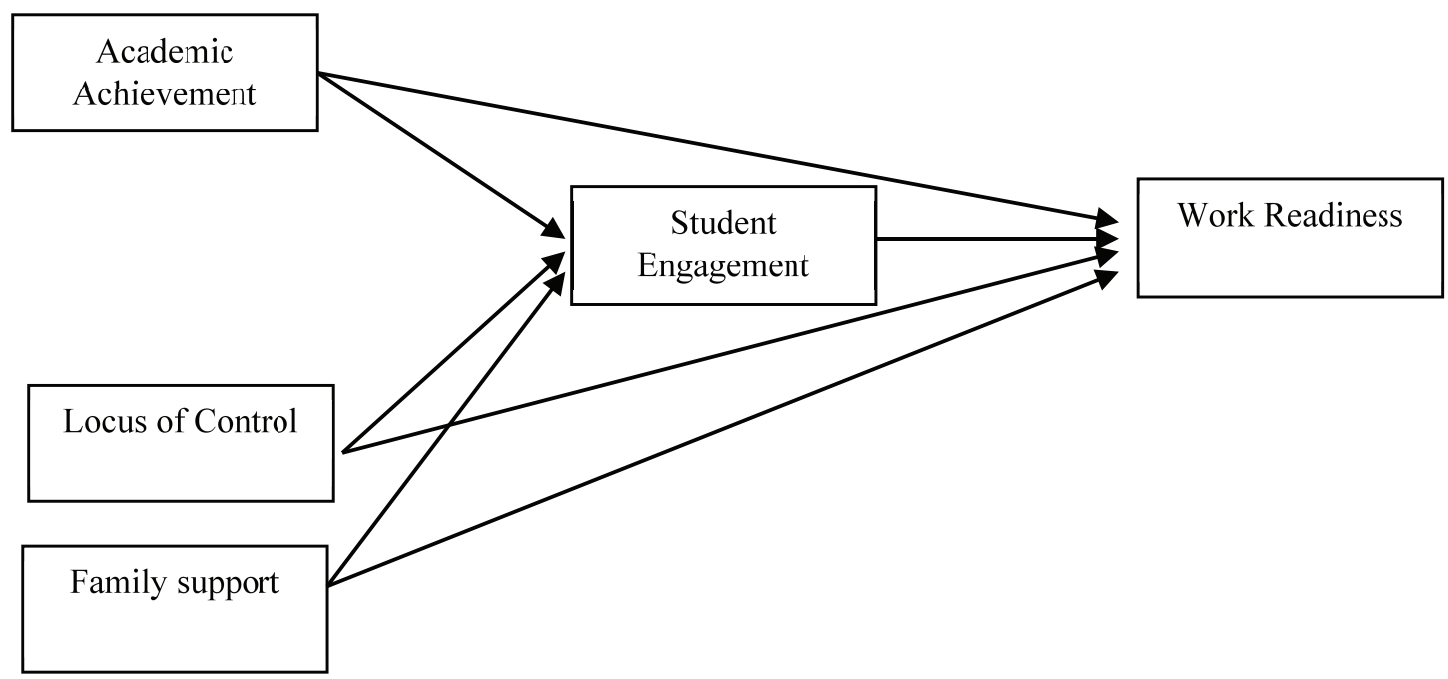

Figure 1: The Diagram of Structural Model.

\section{Results and Discussion}

Before the testing model has built that will be tested, the first test is performed a classic assumption to see the normality of data that has been obtained in field. Normality testing is using AMOS showed that the amount of the Critical Ratio on Multivariate shows numbers 1.73 . When we confirmed with the $Z$ table i.e. amounting to 2.58 then $1.73<2.58$. It means that the data is normally distributed ([7]:253). 
TABLE 1: Operational definitions of variables.

\begin{tabular}{|c|c|c|c|}
\hline Variables & Operational Definition & Indicators & Scale \\
\hline Variables & Operational Definition & Indicators & Scale \\
\hline \multirow[t]{7}{*}{$\begin{array}{l}\text { Work Readiness } \\
(\mathrm{WR}) \rightarrow \mathrm{Y}\end{array}$} & $\begin{array}{l}\text { The initial conditions which must be } \\
\text { owned by a students to respond the } \\
\text { challenge of employment after leaving } \\
\text { school. It means that work readiness is } \\
\text { a step to begin as a modal to work. }\end{array}$ & $\begin{array}{l}\text { 1. Psychological Mental } \\
\text { Readiness }\end{array}$ & Ordinal \\
\hline & & 2. Knowledge Readiness & \\
\hline & & 3. Skills Readiness & \\
\hline & & 4. Discipline & \\
\hline & & 5. Persistence & \\
\hline & & 6. Innovative / Creative & \\
\hline & & 7. Abstinence surrender & \\
\hline $\begin{array}{l}\text { Academic } \\
\text { Achievements of } \\
\text { Study in a } \\
\text { productive } \\
\text { Lessons (AA) } \rightarrow \\
\left(\mathrm{X}_{1}\right)\end{array}$ & $\begin{array}{l}\text { Achievement of study is a measure of } \\
\text { the level of understanding of the } \\
\text { knowledge, attitudes, and skills of } \\
\text { students in Productive subjects } \\
\text { especially Accounting subject obtained } \\
\text { from Summative test }\end{array}$ & $\begin{array}{l}\text { Indicators used in this } \\
\text { variable is the value of } \\
\text { Accounting subjects at } 3^{\text {rd }} \\
\text { grade that has been } \\
\text { categorized into very good } \\
\text { (90-100), good (80-89), } \\
\text { enough (70-79), less (> } \\
70) \text {. }\end{array}$ & Ordinal \\
\hline \multirow[t]{5}{*}{$\begin{array}{l}\text { Internal Locus of } \\
\text { Control (LoC) } \rightarrow \\
\mathrm{X}_{2}\end{array}$} & $\begin{array}{l}\text { It is a condition where students } \\
\text { believe that with effort and hard work } \\
\text { done, then the success and purpose of } \\
\text { life will be achieved }\end{array}$ & 1. Confident & Ordinal \\
\hline & & 2. Optimistic & \\
\hline & & 3. Work hard & \\
\hline & & 4. Rationality & \\
\hline & & 5. Life Experience & \\
\hline \multirow[t]{5}{*}{$\begin{array}{l}\text { Family Support } \\
(\mathrm{FS}) \rightarrow \mathrm{X}_{3}\end{array}$} & $\begin{array}{l}\text { It is the treatment of parents in the } \\
\text { form of support for the activities of } \\
\text { students. This measurement of this } \\
\text { variable refers to the aspects of } \\
\text { perceived support }\end{array}$ & 1. Emotional support & Ordinal \\
\hline & & 2. Award support & \\
\hline & & 3. Instrumental support & \\
\hline & & 4. Information support & \\
\hline & & $\begin{array}{l}\text { 5. Social networking } \\
\text { support }\end{array}$ & \\
\hline \multirow[t]{3}{*}{$\begin{array}{l}\text { Student } \\
\text { Engagement in } \\
\text { Internship } \\
\text { Program (SE) } \rightarrow \\
\text { X4 }\end{array}$} & $\begin{array}{l}\text { Student engagement is shedding of all } \\
\text { physical abilities, mental, and } \\
\text { emotional that students performed at } \\
\text { the time of the implementation of } \\
\text { internship program }\end{array}$ & 1. Physical engagement, & Ordinal \\
\hline & & $\begin{array}{l}\text { 2. The engagement of the } \\
\text { attitude }\end{array}$ & \\
\hline & & $\begin{array}{l}\text { 3. The emotional } \\
\text { engagement }\end{array}$ & \\
\hline
\end{tabular}


After the data is revealed normal distribution, data can be analyzed using the test of conformity research model. The results of the test model in this study showed the following results:

TABLE 2: Testing of The Conformity.

\begin{tabular}{l|c|c|}
\hline Goodness of fit index & Cut-off value & $\begin{array}{c}\text { The Value of Research } \\
\text { Model }\end{array}$ \\
\hline$X^{2}-$ Chi Squere & Expected small & 0,29 \\
\hline RMSEA & $\leq 0.08$ & 0.037 \\
\hline AGFI & $\geq 0.90$ & 0.999 \\
\hline GFI & $\geq 0.90$ & 1,00 \\
\hline CMIN/DF & $0.00 \leq$ CMIN $\leq 422.9$ & 0,29 \\
\hline TLI & $\geq 0.95$ & 0,999 \\
CFI & $\geq 0.95$ & 1,00 \\
\hline Source: AMOS Ver 21.0 output &
\end{tabular}

Based on table 2, it can be known that all of the results test were in the required reception area. Based on table 2 , it also can be seen that the value calculation in the model proposed that meets the acceptance criteria. The results are proving that the model is fit or good. Ferdinand (2014:63) argues that the fit model is the assumption models that are hypothesized to represent data and samples.

The theory is used to build the model and it also uses the student engagement as the dominant factor affecting the input, so it is able to maximal affect output (Astin, 1998). The theory of Astin explained that the engagement of students in their learning environment is very dominant input to change the students input into the expected output. Similar with the theory, the models in this study indicates that student engagement in workplace can increase the readiness of Accounting student at SMK.

The findings of another similar research are the models that built including, Yanto (2012) about the accounting competence as an outcomes of education held at Universitas Negeri Semarang. The study put the motivation of students, the student's convenience and the facilities in learning as Input, then placing the student engagement in learning as the environment. The research from Murray (2006) towards the new student at the University of Maryland. This research explains that an Academic Success as outcomes of higher education which is affected by factors of Environment of First year Experience as measured using Student engagement, Faculty involvement and sense of belonging. Input factor in this research is Student Background characteristic: Gender, High school GPA, and Composite SAT. Each variable is mediated by Student Attributes of Self-Determination, Self-concept, and social self concept. 
After the research model built was declared fit or good, then the data can be analyzed using path analysis. The examination of path analysis undertaken in this study can be seen in graph 1 below:

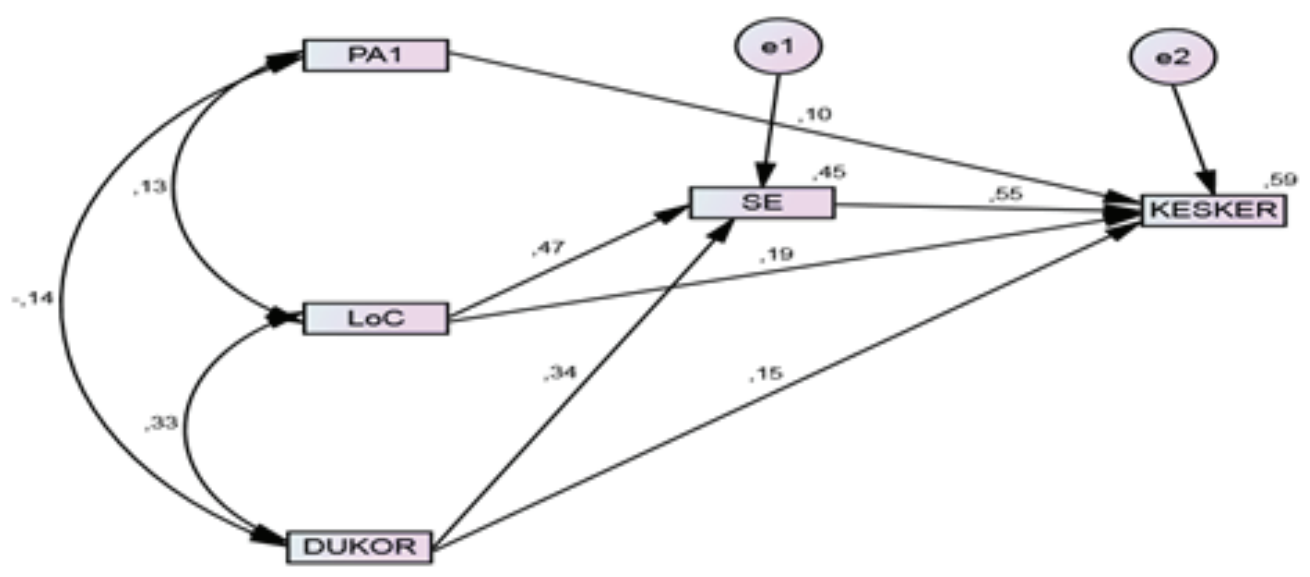

Figure 2: Determination model of Work Readiness.

The further interpretation of the data has presented the following that is the view all of output in this below.

TABLE 3: Regression Weights: (Group number 1 - Default model).

\begin{tabular}{l|c|c|c|c|c|c|c|} 
& & & Estimate & S.E. & C.R. & $P$ & Label \\
\hline SE & $<-$ & AA &, 011 &, 024 & 1,739 &, 243 & par_3 \\
\hline SE & $<-$ & LoC &, 415 &, 044 & 9,436 & $\star \star \star$ & par_8 \\
\hline SE & $<-$ & FS &, 198 &, 029 & 6,844 & $\star \star \star$ & par_9 \\
\hline WR & $<-$ & AA &, 077 &, 032 & 2,439 &, 015 & par_1 \\
WR & $<-$ & LoC &, 208 &, 057 & 3,664 & $\star \star \star$ & par_2 \\
WR & $<-$ & SE &, 696 &, 070 & 9,981 & $\star \star \star$ & par_6 \\
WR & $<-$ & FS &, 111 &, 035 & 3,157 &, 002 & par_7 \\
\multicolumn{2}{l}{ Source: AMOS Ver 21.0 output }
\end{tabular}

The value on the line of curved arrow is the correlation between academic achievement with the Locus of Control, academic achievement with the support of parents, and support of parents with the Locus of Control. In the curved lines between academic achievement with a Locus of Control has a value of 0.13 . It means that the correlation between variables is small. Similarly, the curved lines between the Locus of Control with the support of parents, the support of parents with academic achievement, each shows a value of 0.33 and 0.14 that is included a small correlation because it is still under 0.50 . The small correlation values in the model indicate that the variables are not related and stand-alone. 
The influence of academic achievement showed significant towards work readiness with a probability level of $0.015<0.05$ and the critical ratio of $2.439>2$. It mean that hypothesis $1(H 1)$ is Accepted. The influence of locus of control showed significant towards work readiness with the level of probability of $0.02<0.05$ and the critical ratio of $3,644>2$. It mean that hypothesis $2(H 2)$ is Accepted. The influence of the support of parents showed significant towards work readiness with the level of probability of $0.00<0.05$ and the critical ratio of 3, 157 $>2$. It mean that hypothesis $3(H 3)$ is Accepted. The influence of student engagement on internship program to work readiness showed significant with levels of probability of $0.00<0.05$ and the critical ratio of $9,981>2$. That result can confirmed acceptance of hypothesis $4(H 4)$ is accepted.

Based on the results that have been obtained using the program AMOS, it can be seen that the influence of academic achievement towards the student engagement is not significant with probability $0.243>0.05$ and critical ratio $1.792<2$. It mean that Hypothesis 5 (H5) is declined. The influence of locus of control and the support of parents got a significant result with probability $0.00<0.05$ and critical ratio showed 9.383 and $6.844>2$. It mean that hypothesis $6(H 6)$ and hypothesis $7(H 7)$ is accepted.

To explain the effect of student involvement for increasing the influence of internal factors to Student work readiness can be known from table 4 and table 5. table 4 describes the magnitude of direct influence of locus of control, academic achievement and family support on student work readiness. then table 5 describes the magnitude of the influence of locus of control variables and family support through student involvement in internship program.

TABLE 4: Standardized Direct Effects.

\begin{tabular}{|c|c|c|c|c|}
\hline & FS & LoC & AA & SE \\
\hline SE & 377 & 475 & ,000 & ,000 \\
\hline WR & 178 & 158 & ,095 &, 562 \\
\hline
\end{tabular}

TABLE 5: Standardized Indirect Effects.

\begin{tabular}{|c|c|c|c|c|}
\hline & FAMSUP & LoC & AA & SE \\
\hline SE & , 000 &, 000 & ,000 &, 000 \\
\hline WO & 212 & ,267 &, 000 &, 000 \\
\hline
\end{tabular}

From this table we know that the indirect influence of family support and locus of control is higher than direct influence. It means that student engagement on internship program can increase the locus of control and family support to influence student work 
readiness. This result can confirmed acceptance of hypothesis 8 (H8) and hypothesis 9 (H9). Base on that result $\mathrm{H} 8$ and $\mathrm{H} 9$ is accepted.

That result is consistent with Astin's theory of student involvement. Astin explained that the output of the educational process is not only dominated by internal factors of students, but the process of student involvement in learning also plays an important role in increasing outcomes.

Qualitative analysis in the real findings found that students are very enthusiastic in following or encountering internship program with all the preparation of students. The preparation of the students is trying to find out the conditions of the location and access to place of internship. Besides, students are also trying to find out how the implementation of internship through information from teacher. In addition to the preparation related to the placement of internship, students are also enthusiastic in following the supply and train before doing internship program.

Preparation and enthusiasm of the students in the face of internship program accordance with the concept of locus of control as delivered by Robbins (2007:139) that the locus of control is the level where individuals believe that they are deciding their fate on its own. Thus, it can be seen locus of control students with internship program is in the level of readiness and preparation that done before internship. Students were doing the preparation before they went to internship program. It indicates that students want to gain maximum results during internship program.

Support of parents to students is helping to find a boarding house, shuttling students, and giving extra allowance. In addition to the support of parents among them by giving advice to his son when they are doing internship program.

Similarly, Curtona in Rissa (2013:7) describes that one of family support in education is the instrumental support, i.e. direct support given to children like funding, or helping in tangible form. In addition to the instrumental support according to Curtona, there are also emotional support in the form of attention and advice. family support during their children in internship program it was surely different than just learning in the classroom. The family support can be classified as a form of instrumental and emotional support.

The qualitative analysis showed that there are still many students who placed not accordance with the majors or expertise. It is delivered by teachers who has been hampered on several factors including the following: 1) shortage of industrial or financial institution that can be used as a place of internship, 2) internship program on accounting program has trouble placement in industry or related financial institutions on areas of work in the part of finance which are confidential. 
As a result of inappropriate of placement, many students complained because students unemployed, relaxed and got a job not corresponding with taught in schools. In addition, the students are placed not in accordance with the field of expertise also did not get additional experience from the depth of skills in the field of accounting.

\section{Conclusion}

The conclusions in this study is the student's achievement, Locus of Control, and the family support have positive influenced significantly to Work Readiness of students. Locus of Control and family support influence on student engagement in internship program. The student achievement has not effected significantly to student engagement in Internship Program. Student engagement in internship program contributes in increasing the readiness of the student's work. The implementation of internship program in Purbalingga is still happening of job assignment with competency skills. It occurs because it is still found in the rendering of place for OJT with competence expected.

\section{References}

[1] Alfred, Corinne; Charner, Jhonson, Watts. 2013. "Work Base Learning Opportunities for High School Student" . Journal NRCCTE. University of Louisville, Louisville, KY.

[2] Astin, A.W. 1984. "Student Involvement: A Developmental Theory For Higher Education". Journal of collage Student Development.

[3] Ani, Risa Ari. 2013. "Model Pengembangan Sikap Wirausaha". Journal of Economic Education: PPS Universitas Negeri Semarang.

[4] Bukaliya, Richard. 2012. "The Potential Benefits And Challenges Of Internship Programmes. In An Odl Institution: A Case For The Zimbabwe Open University". International journal of Education: ljonte Publiser.

[5] Curtona E Caroly. 1994. "Perceived Parental Social Support". Journal Personality and Psychology: Emerald Journal.

[6] Creshwell, J.W. 2003. Research Design Quantitative, Qualitative And Mixed Method Approaches. Sage Publication.

[7] Ferdinand, Augusty. 2014. Structural Equation Modelling dalam Penelitian Manajemen. Semarang: AGF Press.

[8] Dixon, Julian. 2012. "Assesment In Student Affairs Using I-E-O Models". Research Report: Michigan State University USA. 
[9] Loekman, Andrew. 2012. "Peran Locus Of Control dan Justice terhadap Ekskalasi Komitmen dalam Penggunaan Modal". Berkala Ilmiah Mahasiswa: Akuntansi UNIKA Widya Mandala Surabaya.

[10] Mizikaci, Fatma. 2006. "A System Approach to Program Evaluation for Quality in Higher Education". Emerald Jurnal

[11] Moelong, Lexy J. 2007. Metode Penelition Kualitatif. Bandung: Rosdakarya

[12] Murray, Michele C. 2006. Reframing Responsibility For Academic Success: A Causal Model Measuring The Impact Of Student Attributes In The First Year Of College. Disertation. University of Maryland

[13] Norwani, Rohalia, Muhd Khairudin. 2003. "Learning Outcomes at Higher Education: To What Extent do institutional Environments Contributes". The Journal of Human Resource and Adult Learning Vol. 5: Sultan Indris Education University Malaysia

[14] Rissa, Putri Tiara. 2013. "Hubungan Antara Dukungan Sosial Orang Tua dengan Motivasi Menyelesaikan Skripsi Mahasiswa Psikologi". Research report: Universitas Bina Nusantara

[15] Stephen, Robbin. 2001. Psikologi Umum. Jakarta: Balai Pustaka

[16] Yanto, Mula \& Kavanagh. 2012. "Developing student's accounting competencies using Astin's I-E-O model: An identification of key educational inputs based on Indonesian student perspectives". International Journal: University of Soutern Quensland Australia

[17] Zou, Juan. 2010. "The Impact of Engagement on Academic Performance and Presistance of First Year Colage Student at Public Institution". Journal University of Florida. 